\title{
AHOL A NYELVTANULÁS GYEREKJÁTÉK - ANGOL NYELVI FEJLESZTÉS A CSATA UTCAI ISKOLÁBAN
}

\section{Kovács Judit}

Eötvös Loránd Tudományegyetem

\section{Pedagógiai innováció}

Van Budapesten egy iskola, ahol minden délután egy és öt között angolul zajlik az élet. Angol nyelvű napközinek is mondhatnánk, ha csupán azt a tényt vesszük figyelembe, hogy a programra a napi tanórák után kerül sor. A Boys and Girls Activity Center of Hungary BGAC, mint a neve is mutatja, Amerikából érkezett. Az Amerikai Egyesült Államokban és más tengerentúli országokban már 4 millió kisiskolás tölti délutánjait a Boys and Girls Club of America által kínált program keretei között. Európában a Manó-Világ Kft. által müködtetett BGAC az egyetlen klub, amely megkapta a jogot, hogy a BGAC által kidolgozott pedagógiai innovációkat tartalmazó programokat használja ${ }^{1}$.

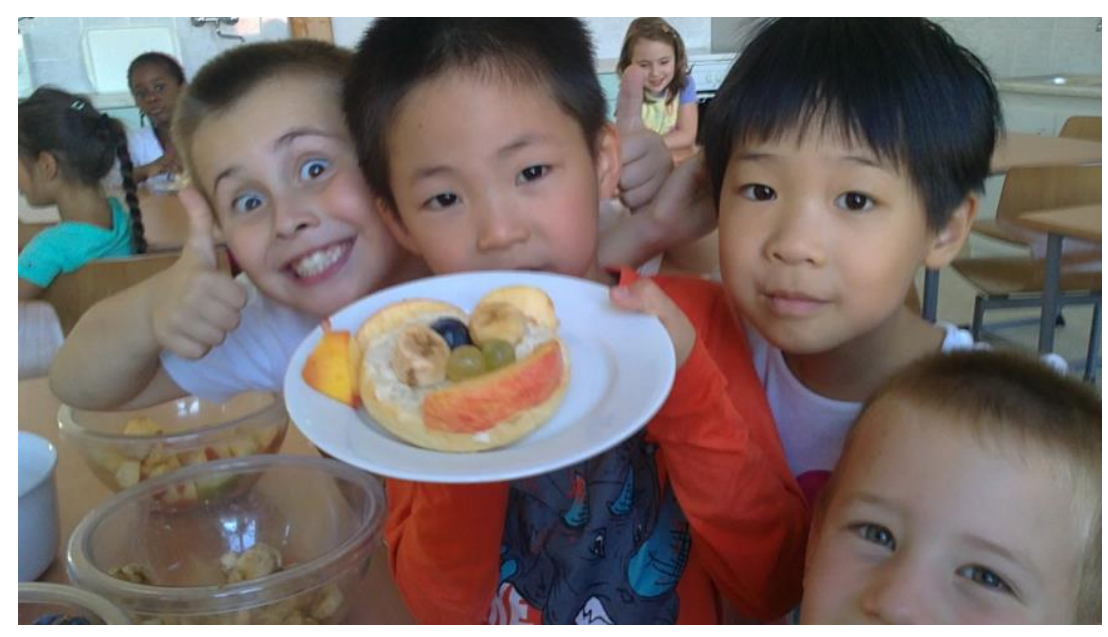

\section{Az előzmények}

Az angol nyelvű gyermekklub életrehívása szorosan kapcsolódik ahhoz a tényhez, hogy a XIII. kerületben 2011 szeptemberében megkezdte müködését egy magyarangol kétnyelvü óvodai program, a Manó-Világ Kft. közremüködésével. Az óvoda felmenő rendszerben, egyenletesen bővülve jelenleg már hat csoporttal müködik. A magyar pedagógiai programmal párhuzamosan, párban valósítják meg az angol nyelvi programot, amelynek keretében kizárólag angol anyanyelvü pedagógusok foglalkoznak a gyerekekkel.

A program sikerének hatására már az első év végén felmerült Erdélyi Nóra szakmai vezetőben és Horváth Mónikában, a kft. ügyvezetőjében, az óvodai program iskolában való folytatásának gondolata. Így jutottak el a BGAC-típusú,

\footnotetext{
${ }^{1}$ A fényképeket Kovács Judit készítette a tanulmány illusztrálásához.
} 
délutáni angol elfoglaltságot nyújtó verzióhoz, amelynek bevezetését nagymértékben megkönnyítette Szenteiné Bukovinszky Katalinnak, a Csata utcai általános iskola igazgatójának az ügy iránti elkötelezettsége. Az óvoda- és az iskolavezetés elképzelése találkozott a helyi önkormányzat munkatársainak az elképzelésével. A programválasztáshoz segítséget nyújtott az óvoda vezető angol nyelvü pedagógusának szakmai tapasztalata, aki az USA-ból Magyarországra költözése elött tíz évig a BGAC munkatársa volt.

\section{A program}

A BGAC program nagy előnye, hogy szervesen beilleszthető a hazai közoktatás rendszerébe. Nem igényli a meglévő keretek megváltoztatását, mivel a délelőtti tantítás menetét nem érinti. Az angolnyelvűség kizárólag a délutánokra korlátozódik, a hazánkban megszokott napközis foglalkozás idejében. A délután 1-5-ig terjedő időkeretbe sok hasznos tevékenység fér bele: sport, kézmüves foglalkozás, közös játék, beszélgetés, sőt: főzés is.

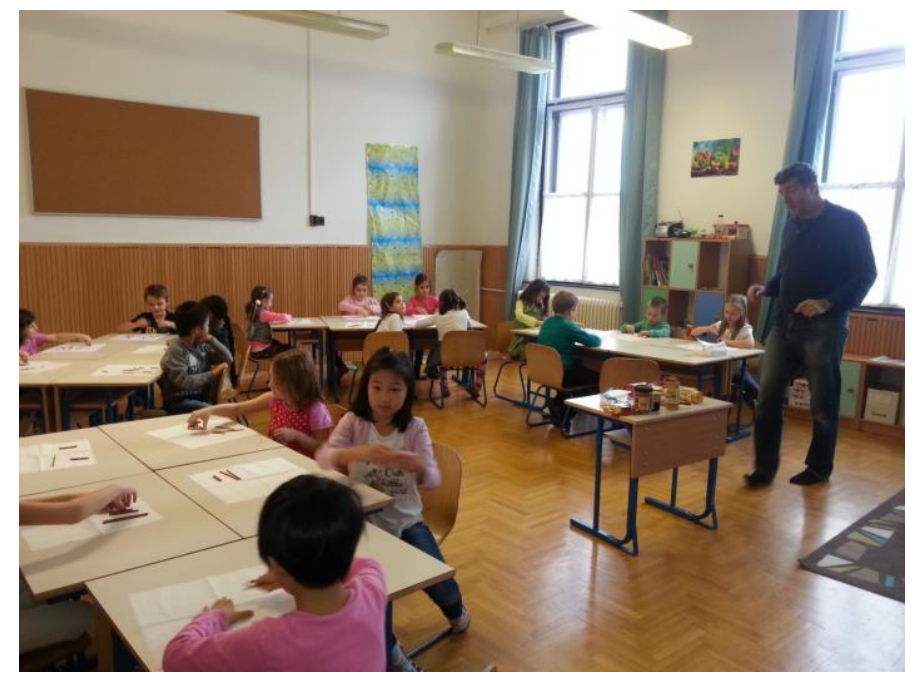

A napi rutin a következö: az ebédet követően, az időjárástól függően, a szabadban játszanak a gyerekek, ez után, a gyerekek fele, azaz 10-12 gyerek a házi feladatát készíti el, miközben az osztály másik felével az angol pedagógus kiscsoportos, de nem tanórai jellegü formában foglalkozik. Ezután, a nap fókuszának megfelelő tevékenységek zajlanak: sport, dráma, interaktív táblás foglalkozás, kézműves foglalkozás, háztartási és egészséges életviteli ismeretek, melyek keretében a gyerekek az erre a célra berendezett konyhában együtt főznek, illetve cserépben füszernövényeket termesztenek. Az öt délután három angol nyelvü pedagógus között oszlik meg. Hétfőn, szerdán és pénteken Mark, kedden Anna, csütörtökön pedig Andrew foglalkozik a gyerekekkel. Mindhárman délelöttönként az óvodában dolgoznak, így az óvodai programban előzetesen részt vett gyerekek elött már nem ismeretlenek. 
A foglalkozások nagymértékben eltérnek a hazánkban szokásos napközis foglalkozásoktól. A gyerekek nem padban ülnek, hanem a szőnyegen, kihasználva a nagy termek adta lehetőségeket. Iskolai értelemben vett „tanulás” sem történik, különben hiába is várnánk a gyerekektől lelkesedést a nap hatodik, hetedik, sőt, további órájában. Inkább nevezhetnénk önként és kedvvel vállalt szakköröknek, amelyeknek mindegyike valamilyen, a gyerek számára értelmes tevékenység köré szerveződik.

\section{Az angol nyelvi fejlesztés módja}

A tíz éven aluli korosztállyal foglalkozó szakemberek körében már egyértelmüen elfogadott az a tény, hogy a gyermek akkor tanul a legeredményesebben, ha azt számára érthető kontextusban, korának megfelelö tevékenységek közepette teszi.

A kézmüvesség, mozgás, sport, mesélés, éneklés, társasjátékok - mind ilyen foglalatosságok. A program nem kíván semmi olyat a gyerekektől, ami világuktól idegen, vagy fölöslegesen megterhelö. Csupán olyan tevékenységeket kínál számukra, amit anyanyelvükön is szívesen csinálnak. Mivel az élvezettel végzett tevékenység a tanulás alapja, nem meglepő, hogy a szokásos iskolai keretek: számonkérés, házi feladat, osztályzás nélkül is igen eredményes a nyelvelsajátítás.

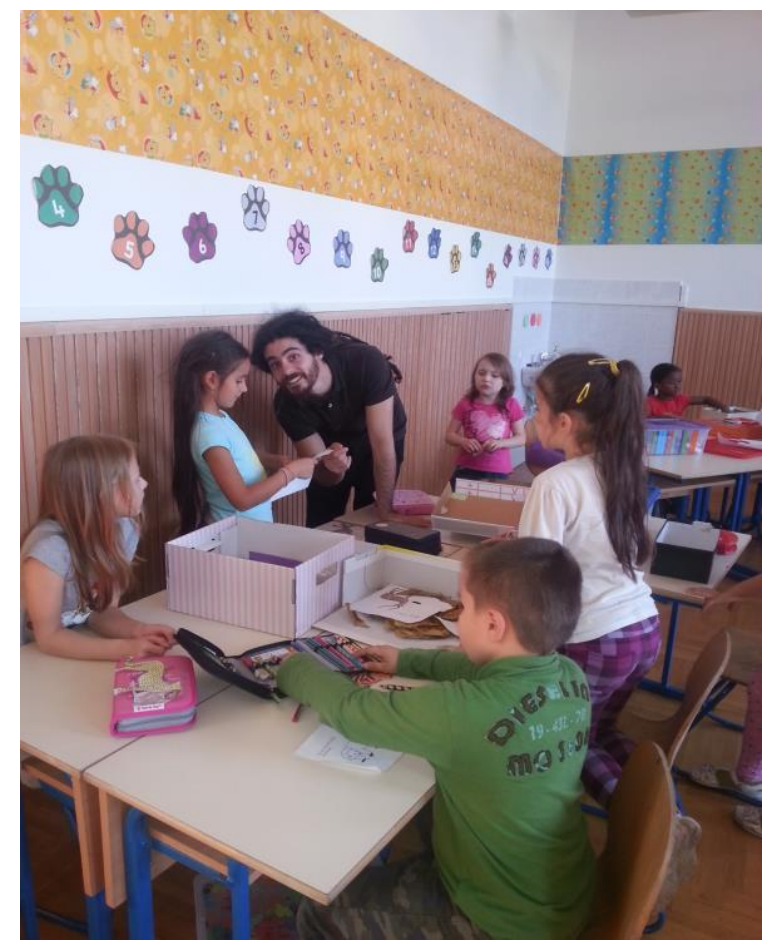

A BGAC keretében a gyerekek nem vesznek részt semmi olyan tevékenységben, amelyet hagyományosan a legkisebb mértékben is angol órának lehetne nevezni. Nincs tankönyv, füzet, dolgozat, osztályzat. A keretek nem a közoktatás keretei: nincs NAT-elöírás, kerettanterv. Az így elért szabadság nagy 
lehetőséget nyújt az egyéni fejlesztésre. Az angol nyelvü pedagógusokkal eltöltött napi 4 (heti 20) óra lényegében sokkal intenzívebb kapcsolatot jelent a nyelvvel, mint a szokásos heti 2-3 órás tanórai keretek.

\section{Milyen egy angol nyelvü klubfoglalkozás?}

December elején többedmagammal részt vettem egy drámafoglalkozáson, amelyet az USA-ból érkezett Anna tartott. A gyerekekre rápillantva az első benyomás mindenképpen a sokszínűség volt: legalább egynegyedük nem európai. Négy ázsiai és egy fekete tanuló is jár az osztályba, ezzel is megerősítve, hogy a program célja a többnyelvü nevelés. Azok a szülők, akik ide beíratják gyermeküket, tisztában vannak ezzel a sokszínüséggel, valamint azzal, hogy ez a sokszínüség alkalmanként a pedagógusokra is vonatkozik.

Anna nagyszerű mesemondó készséggel rendelkezik, és jól él a nem verbális kommunikáció eszközeivel, amelyek elsődlegesek a megértés segítésében. A 45 perces foglalkozás (mi ezt anyanyelvi irodalomórának mondanánk) egy sodró erejü rímes mese közös elmondásával kezdődött. Az impozáns hosszúságú tevékenység minimum 10 percig tartott. A gyerekek a nagy klubszoba egyik sarkában, a szőnyegen, néhányan babzsákon ültek, Anna is köztük ült. Ennek az ülésrendnek az az előnye, hogy a szőnyegen bőven elférnek a szó- és képkártyák, a gyerekek és a tanár számára is könnyen elérhető módon.

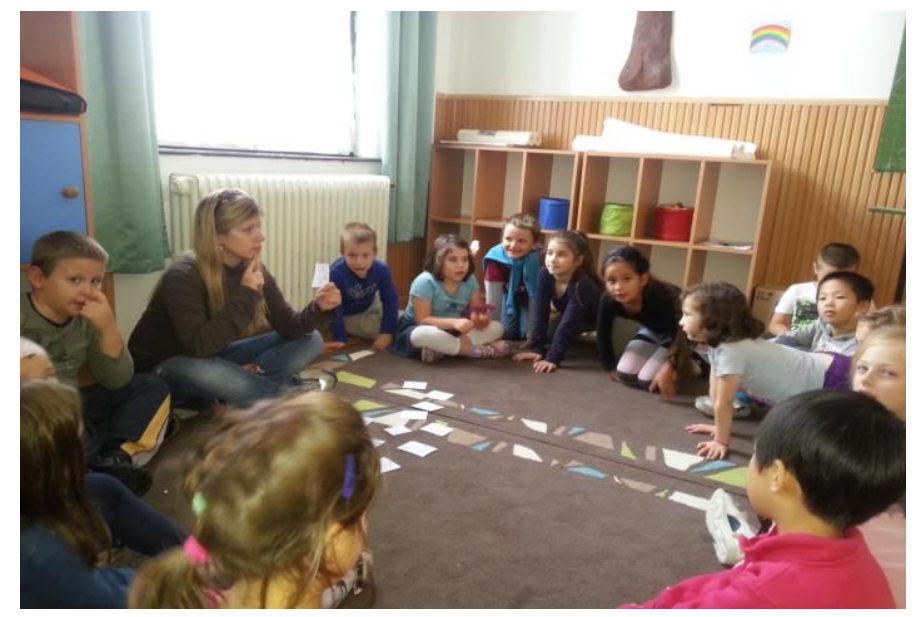

Ugyanakkor mégis különbözik a padban ülés és a füzetbe írás iskolás fegyelmétől. A gyerekek szemmel láthatóan élvezték a rímes sorokat, amelyet értettek is. Ezt követte a közösen elmondott vers rímeinek felismerése, valójában egy rímes játék, melynek során a pedagógus által felmutatott angol nyelvü szókártyához a szőnyegre kirakott szavak között rímes párokat kell találni. Egy pár példa: hat-cat, fox-socks, hair-chair stb. A feladat igen összetett, hiszen egyszerre irányul az olvasási készség és a kiejtés, mint kompetencia fejlesztésére egy olyan életkorban, amikor még az anyanyelven történő olvasás is újdonság. A rímek ereje azonban úgy tủnik, győzedelmeskedik, mert a gyerekek élvezettel és 
lelkesen dolgoznak a feladaton, egy-egy szóhoz esetenként több rímelő szót is találnak. A foglalkozás további részében egy komplett angol mese, (The Gingerbread man, azaz a Mézeskalács-emberke) nagyon részletes feldolgozását láthattuk. A mese meghallgatása után a gyerekek mintegy rögtönzött színielőadást tartottak, megelevenítették a mesét. A 45 perces foglalkozás kizárólag angolul folyt, a gyerekeken azonban a fáradtság legkisebb jeleit sem lehetett látni, hiszen mindvégig játszottak. A szabadidős tevékenység jelleget az is biztosította, hogy semmiféle tanulság levonása nem történt meg a mese végén, és természetesen, házi feladatot sem kaptak a gyerekek.

\section{Összegzés: a BGAC-program helye a hazai közoktatásban}

A Csata utcai iskolában folyó BGAC-program hiánypótló szerepet tölt be a hazai korai idegen nyelvi fejlesztésben. A kizárólag célnyelvü pedagógusok alkalmazása okán a közoktatásban másutt nem tapasztalható minőségben és intenzitással, a korosztály igényeit messzemenően figyelembe vevő módon kínál lehetőséget a korai angol nyelvi fejlesztésre. Az eddigi eredmények alapján a jövő tanévre már két ilyen osztály indítására kapott engedélyt az iskola. Bizakodásra ad okot, hogy a hazai átlagot meghaladóan népes gyermekszámmal rendelkező angyalföldi lakótelep egyik iskolája élen jár ennek az európai viszonylatban is innovatív képzési formának az elindításában. 